\title{
KARANJ (PONGAMIA PINNATA) - AN AYURVEDIC AND MODERN OVERVIEW
}

\author{
SHIFALI THAKUR, HEMLATA KAURAV, GITIKA CHAUDHARY
}

Shuddhi Ayurveda, Jeena Sikho Lifecare Pvt. Ltd. Zirakpur 140603, Punjab, India. Email: shuddhi.reasearch@jeenasikho.co.in

Received: 09 March 2021, Revised and Accepted: 23 April 2021

\begin{abstract}
Pongamia pinnata is one of the significant herbal plants with different therapeutic medicinal properties. P. pinnata is a potential medium-sized legume tree, also known as Karanja. It is widely distributed in Indian Western Ghats. This plant is mostly cultivated around coastal areas, riverbanks, tidal forests, and roadsides. Conventionally, the leaves, seeds, and the whole plant were utilized in the treatment of many ailments. There are various phytochemicals isolated from the P. pinnata plant. Karanjin is the principal furanoflavonoid of the plant. It was known to be the first crystalline compound isolated from this plant. The plant is therapeutically important in traditional medicine as well as in modern drugs. Oil extract from the $P$. pinnata seeds is utilized in agriculture and pharmacy. Seed oil is also proved to be a biofuel in recent studies. There are various therapeutical uses of the P. pinnata, including antiulcer, anti-diarrheal, antiplasmodial, anti-inflammatory, anti-viral, anti-bacterial, anti-lice, and others. The karanja seeds contain $27-40 \%(\mathrm{w} / \mathrm{w} /)$ oil. Commercially, the seed oil of the P. pinnata is used as biodiesel. The present review article reveals the overall ayurvedic and modern therapeutic information of $P$. pinnata with various reported ayurvedic literature and scientific pharmacological studies.
\end{abstract}

Keywords: Karanj, Pongamia pinnata, Anti-inflammatory, Anti-plasmodial, Folk uses.

(C) 2021 The Authors. Published by Innovare Academic Sciences Pvt Ltd. This is an open access article under the CC BY license (http://creativecommons.org/ licenses/by/4.0/) DOI: http://dx.doi.org/10.22159/ajpcr.2021v14i6.41367. Journal homepage: https://innovareacademics.in/journals/index.php/ajpcr

\section{INTRODUCTION}

Medicinal plants play an important role in human lives for many years to treat various diseases all over the world. Plants are the diverse producer of bioactive compounds that make them a rich source of different types of medicines [1]. Today, there is widespread interest in drugs obtained from natural plants for their various therapeutic properties. Pongamia pinnata Linn Pierre (Fabaceae) is a fast-growing medium-sized tree that belongs to the Leguminosae family [2]. It is an important non-edible minor oilseed tree. It is also called as "Karum Tree" or "Poonga Oil Tree" in English [3]. It is native mainly to hot arid regions of Asia. The trees Pongamia are cultivated commercially in India. Therapeutic uses of this plant are also found in the literature of the traditional medicinal system. Karanja (P. pinnata) (Fig. 1) is an ancient plant of Veda, Samhita, and almost in all Nighantu (Dictionary) [4]. It includes various chemical compounds such as alkaloids, flavonoids, tannins, glycosides, hormones, karangin, glabrin, kanugin, fixed oils, and others [5] that possess various potential anti-inflammatory, anti-nociceptive, antioxidant, antidiarrheal, anti-fungal, anti-plasmodial, anti-ulcer, anti-hyperglycemic, anti-oxidative, anti-hyperammonemic, and analgesic functions [6,7]. All parts of the plant $P$. pinnata have been considered as a crude drug [8]. It is also used in the field of environment and agriculture. The seeds of the plant are known as potential biodiesel sources [9] that contain around $28-34 \%$ oil with a high concentration of polyunsaturated fatty acids [10]. P. pinnata contains a dense network of lateral roots that have been known to prevent soil erosion. There are several methods reported for the cultivation of plants, including direct seed sowing or by raising the seeding in the nursery and planting by stump cuttings. However, seed sowing is most common because it does not require pre-treatment and grows within 1 week to a month [11]. The tree has a vast medicinal, economical significance due to widespread usage of every part, especially seeds and roots [12]. This review paper aims to provide whole information on the general information, phytochemicals, and various medicinal application of the plant $P$. pinnata. Taxonomy and vernacular names of $P$. pinnata (L.) are given in Tables 1 and 2, respectively.

P. pinnata Linn pierre is also known by various synonyms such as [13]

- Millettia pinnata (L.) Panigrahi

- Pongamia glabra vent

- Derris indica (Lam)

\section{BOTANICAL DESCRIPTION OF P. PINNATA}

According to Allen and Allen (1981), the plant P. pinnata is a fastgrowing tree that grows up to 40 feet in height and spreading a canopy casting moderate shade. It is a medium-sized, evergreen, perennial, and deciduous tree (Fig. 1) and its height range up to 35-40 feet, fastgrowing, and medium texture. Leaves are alternate, odd pinnately compound, wide up to 2-4 inches, evergreen, and hairless. Flowers are lavender, pink, and white, 2-4 together having short-stalked, peashaped long up to 15-18 mm. Pods are smooth, brown, thick-walled, hard, and indehiscent. It is $3-6 \mathrm{~cm}$ long and $2-3 \mathrm{~cm}$ wide. Seeds are compressed, ovoid or elliptical, oily, been-like, and 10-15 cm long. Lateral roots are numerous and well developed and taproot is thick and long. Bark changes its color from thin gray to grayish-brown and it is yellow from inside [14].

\section{GEOGRAPHICAL DISTRIBUTION OF P. PINNATA}

P. pinnata is widely distributed in Asia. This is now found in Australia, Florida, Hawaii, India, Malaysia, Oceania, the Philippines, and Seychelles [15]. It is found in South India up to an altitude of $1200 \mathrm{~m}$. It is naturally grown near streams and rivers. Its best growth is found in drained sandy loams with assured moisture [16].

\section{PHYTOCHEMICAL CONSTITUENTS OF P. PINNATA}

There are various chemical constituents isolated from the plant $P$. pinnata. Flavonoid and its derivatives are the most common constituents for isolation. The derivatives of flavonoids are flavones, flavans, and chalcones. Sesquiterpene, diterpene, triterpenes, steroids, amino acids, disaccharides, fatty acids, and ester compounds are also detected in this plant.

\section{Flavones}

These are the most common constituents extracted from P. pinnata. The flavone class of compounds is distributed in all parts of this plant. Karanjin was considered the first compound to be extracted from this plant. Simple flavones, methylenedioxy flavones, furanoflavones, chromenoflavones, glycosidated flavones, glycosidated isoflavones, isofuranoflavone, prenylated isoflavones, and flavones with modified rings such as coumestan, rotenoids and pterocarpans, and a diflavone 


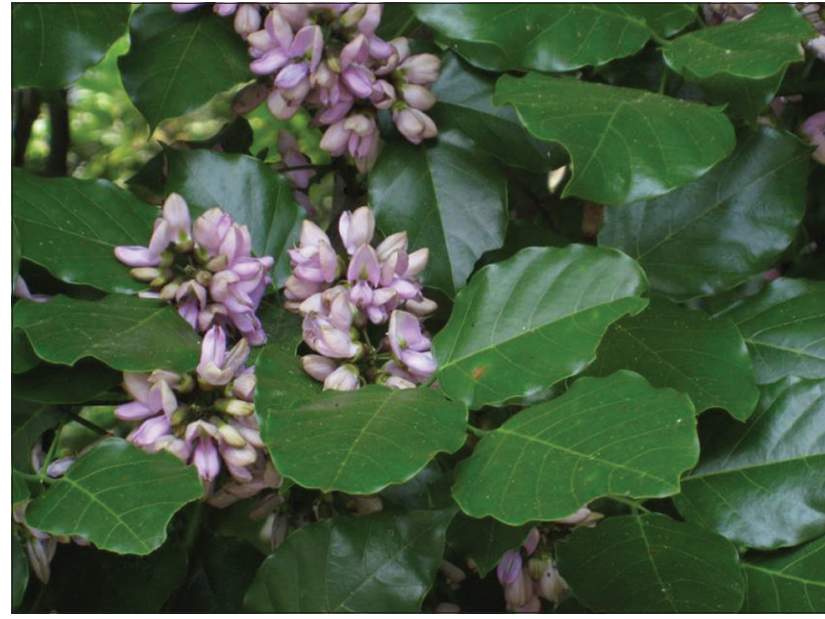

Fig. 1: Pongamia pinnata (Indian Beech Tree)

Table 1: Vernacular names for P. pinnata (L.)

\begin{tabular}{ll}
\hline Vernacular name & \\
\hline English & Indian beech \\
\hline Hindi & Karanj, Kanja, Karanja \\
Sanskrit & Ghrtakaranja, Karanjaka, Naktahva, Naktamala \\
Urdu & Karanj \\
Punjabi & Karanj \\
Assamese & Korach \\
Bengali & Daharakaranja, Karanja, Natakaranja \\
Gujrati & Kanaji \\
Kannada & Honge \\
Malayalam & Pungu, Ungu \\
Marathi & Karanja \\
Oriya & Karanja \\
Tamil & Pungai \\
Telugu & Ganuga, Kanuga \\
\hline
\end{tabular}

P. pinnata: Pongamia pinnata

Table 2: Botanical classification of P. pinnata (L.) [3]

\begin{tabular}{ll}
\hline Taxonomical rank & Taxon \\
\hline Kingdom & Plantae \\
Division & Magnoliophyta \\
Class & Magnoliopsida \\
Order & Fabales \\
Family & Leguminosae \\
Genus & Pongamia \\
Species & Pinnata \\
Common Name & Karanja, Indian beech \\
\hline
\end{tabular}

P. pinnata: Pongamia pinnata

have been isolated from this plant. Furanoflavone is first isolated from the seed oil. Limaye (1925) was succeeded to obtain their structure [17]. He proved that the molecule of Karanjin consisted of 3 fused rings, of which at the center, the carboxylic benzene nucleus had on either side one ring each, containing oxygen atoms besides carbon. There is a total of 13 colorless crystals in which simple flavone such as fisetin tetramethyl ether, 3,7-dimethoxyflavone, Luteolin, 7-0-methylchrysin, 7,4'-dimethoxy-5-hydroxyflavone, Kaempferol, and quercetin have been isolated from all the parts of the plant, except the seed. Kaempferol is recent to be isolated from P. pinnata [18]. Kanugin is a methylenedioxy flavone that was also extracted from roots, flowers, stem bark, and other parts of the plant. Demethoxykanugin loses a methoxy group attached to the B ring extracted from the flower, stem bark, and root bark [19-22].

Pongapin is the second furanoflavone found in the species that were isolated from the root bark [23]. After that, several farina flavones have been isolated from the seed, flowers, fruits, stem bark, and root-like 3,4-methylenedioxyflavone, kanugin, 3-methoxy furol [8,7:4",5"] flavone, pongaglabol methyl ether, pachycarin D, Pongol, Pongaglabol, kanjone, 6-methoxyisopongaglabol, 6-methoxyisopongaglabol methyl ether, Pongapinnol C, Pongapinnol D; 2',5'- dimethoxy furi [8,7:4".5"] flavone, Millettocalyxin C, Pongapinnol B, Pongapinnol A; 3,3', $4^{\prime}$-trihydroxy4H-furo[2,3-h] chromen-4-one, Pongaglabrone, Pongapin, 5-methoxy$3^{\prime}, 4^{\prime}$-methylenedioxyfurano $\quad\left(8,7-4^{\prime \prime}, 5^{\prime \prime}\right)$ flavone, $2^{\prime}$-methoxy- $4^{\prime}, 5^{\prime}$ methylenedioxyfurano $\quad\left[7,8: 4^{\prime \prime}, 5^{\prime \prime}\right]$-flavone; $\quad 3^{\prime}$-methoxypongapin; Pinnatin, Glabone, Ponganone XI, and Pongamone D [6,24-27]. No flavones are found to be present in the leaves. Pongaglabol is a new compound isolated from the flower. Pongachromene, a methylenedioxy chromenoflavone, was the first chromenoflavone to be reported from P. pinnata. Karanjachromene is also known as Pongaflavone, is isolated from the plant [28]. Other chromenoflavones were reported in a period of 27 years from 1983 to 2003 [29].

Glycosidated flavones were also isolated from this species [30]. Pongamoside A, Pongamoside B, Pongamoside C, and Pongamoside D are the first four glycosidic flavones isolated from the fruit of this plant. It was the first time such compounds were found as naturally occurring ones. Kaempferol 3-0- $\beta$-D-rutinoside, Rutin, Vicenin-2, 4'-0-methylgenistein 7-O- $\beta$-D-rutinoside, and $2^{\prime}, 5^{\prime}$-dimethoxy-genistein 7-0- $\beta$ Dapiofuranosyl-(1"-6")-0- $\beta$-Dglucopyranoside are the flavonoid diglycosides isolated from the leaves [31,32]. Furanoflavone and isoflavones in prenylated form were extracted from the root and stem bark $[33,34]$. Coumestan, retinoids, and pterocarpans are the flavonerelated compounds obtained from this plant. Pongamiaflavonylflavonol is the first diflavone found from this species $[35,36]$. It is a compound having 6 carbons in flavone skeleton, bound to carbon 8 of the other flavone one [2]. The structures of flavones of P. pinnata are shown in Fig. 2.

\section{Flavans}

Flavans are distributed in almost every part of the species, especially in leaves [37]. Only 2 compounds are non-flavanone from this class and they are Pongamone E and pongaflavanol, both flavan-4-ol derivatives. A new compound (2S)-5,7-dimethoxy-8-formylflavanone is a simple flavone containing formyl group also isolated from this plant [38]. Flavans present in various part of the plant are:

1. Stem: The flavones isolated from stem and stem bark are (2s)-5,7-dimethoxy-8-formylflavanone, Pongamone E; 3,4-methylenedioxy-(4",5",7,8)- furanoflavanone; Pongachin; Pongamone B; Pongaflavanol; Ovaliflavanone A; Candidone; (2s)-5,7- dimethoxy-8-(2R- hydroxyl-3-methyl-3-butenly) flavanone; (2S)-5,7-dimethoxy-8-(2S-hydroxy3-methyl-3butenyl) flavanone; (2S)-5,7-dimethoxy-8-(2S-hydroxy3-methyl3-butenyl)-3', ' $^{\prime}$ - methylenedioxyflavanone; Pongapinone B; Pongamone C, and 6,7,2",2"-dimethylchromono-8- dimethylallyl flavanone [39]. Chemical structures of some flavones of $P$. pinnata are shown in the Fig. 3

2. Fruits: $(2 S)-\left(2^{\prime \prime}, 3^{\prime \prime}: 7,8\right)$-furanoflavanone categorized as furanoflavanone is isolated from the fruit part of the plant [40]

3. Root: Four compounds are isolated Ponganone III; Ponganone IV; $\mathrm{O}$-isoglabrachromene and Ponganone V from the root and root bark of the plant [41]

4. Flower: Ovalichromene B is the only flavan compound isolated from flowers of P. pinnata [42].

\section{Chalcones}

Twenty-five compounds are dominated by furanochalocones and chromenochalcones and come under chalcone class. They are written below:

- Root Bark: 2'-hydroxy-3,4,4', 6'-tetramethoxychalcone, Ponganone X, Milletenone, Ponganone VII, Dihydromilletenone methyl ether, Ovalitenin B, Ponganone IX, Glabrachromene, and Ovalitenone are the chalcones compounds isolated from $P$. pinnata

- Stem: Tunicatachalcone, 7-methoxypraecansone B, Pongapinone A, Glabrachromene, and Ovalitenone 
<smiles>COc1c(-c2ccccc2)oc2c(ccc3occc32)c1=O</smiles>

a. Karanjin

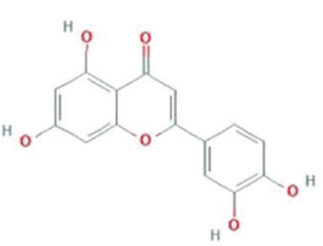

\section{e. Luteolin}

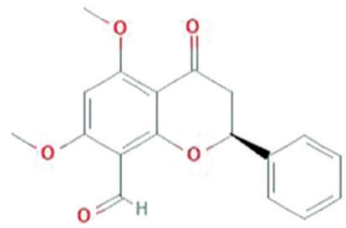

a. (2S)-5,7-dimethoxy-8formylflavanone

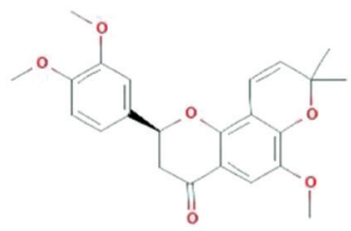

e. Ponganone IV<smiles>O=c1c(O)c(-c2ccc(O)cc2)oc2cc(O)cc(O)c12</smiles>

b. Kaempferol<smiles>COc1ccc2c(=O)c(OC)c(-c3ccc(OC)c(OC)c3)oc2c1</smiles><smiles>COc1ccc2c(=O)c(OC)c(-c3ccc4c(c3)OCC4)oc2c1</smiles>

g. Demethoxykanugin<smiles>COc1ccc2c(c1)Oc1cc(-c3oc4cc(OC)ccc4c(=O)c3OC)cc(OC)c1O2</smiles>

\section{d. Kanugin}<smiles>O=c1cc(-c2ccccc2)oc2c1ccc1occc12</smiles>

h. Lanceolatin B

Fig. 2: Flavones of Pongamia pinnata and their derivatives

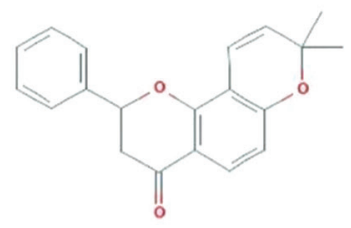

b. Isolonchocarpin

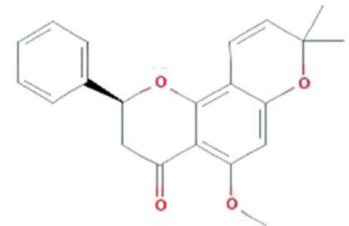

d. Pongachin

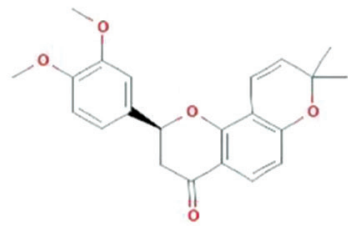

d. Ponganone III<smiles>CC1(C)C=Cc2c(ccc3c2OC(c2ccc4c(c2)OCO4)CC3=O)O1</smiles>

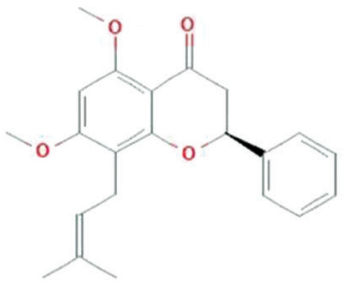

g. Candidone

Fig. 3: Flavones of Pongamia pinnata and their derivatives

- Seed/flower/Root: Pongamol, Obovatachalcone, and Glabrachalcone [43]

- Leaves: Pongagallone A and Pongagallone B [44]

- Pods: Pongamiabiaurone [45]

- There are some unique facts to be observed about the flavonoids found in this species. From the three classes of flavonoids (flavones, flavans, and chalcones), neither furano nor chromene compounds are found in the leaves of this plant. Furthermore, glycosidated compounds only exist as flavones and were only found in the fruit and the leaf part. Chemical structures of chalcones of $P$. pinnata are shown in Fig. 4.

\section{Miscellaneous compounds}

Several miscellaneous compounds were also reported to occur in all parts of this plant [27]. Terpenoids exist as sesquiterpene, diterpene, and triterpenes. Most of the terpenes are detected in the stem bark except Cycloart-23-ene-3 $\beta, 25$-diol and Friedelin, which were isolated from the flower part. $\beta$-sitosterol and stigmasterol along with their acetate are 
<smiles>COc1cc(O)c(C(=O)/C=C/c2ccc(OC)c(OC)c2)c(O)c1</smiles>

a. 2'-hydroxy-3,4,4', 6'tetramethoxychalcone<smiles>COc1ccc(C(=O)CC(OC)c2ccc3c(c2)OCO3)c(OC)c1</smiles>

\section{d. Dihydromilletenone} methyl ether

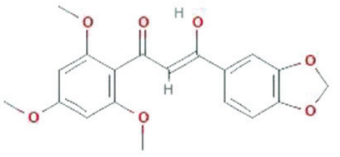

b. Ponganone $\mathrm{x}$

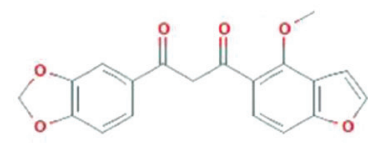

e. Ovalitenone

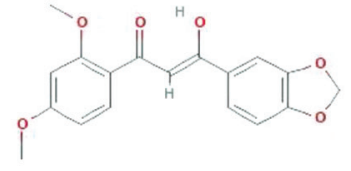

c. Milletenone

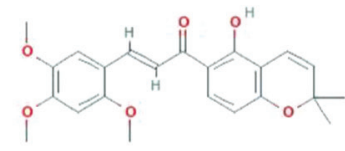

f. Glabrachalcone

Fig. 4: Chalcones of Pongamia pinnata and their derivatives

distributed in the flower and seed. Furthermore, glycosidated forms of the sterols also occur in the species. $\beta$-sitosterol galactosides and stigmasterol galactosides along with $\beta$-sitosterol-3-O- $\beta$-D-glucoside and Stigmasterol-3-0- $\beta$-D-glucoside and sucrose, were reported for the first time in this plant by Shameel et al. (1996). Bis (2-methylheptyl) phthalate, an aromatic ester, was the only miscellaneous compound found in this plant reported to occur in the leaves $[2,46]$.

\section{TRADITIONAL AND MODERN VIEW}

\section{Folk view}

Karanja plant is a medicinal plant since ancient times. According to Hartwell (1967-1971), in India, the sprouts and fruits are utilized in folk remedies for abdominal tumors, the seeds for keloid tumors in Sri Lanka and plant powder are used for tumors in Vietnam [17]. Every part of the plant having ethnobotanics properties. The seed oil of P. pinnata is utilized in itches, abscesses, and other skin diseases [47]. Flowers are used as a remedy for diabetes problems [19]. Bark of the plant is used internally for bleeding piles, beriberi and diabetes, and anti-hepatoprotective activity [20]. Leaves were used as a medicated bath for relieving rheumatic pains and for cleaning ulcers in gonorrhea and scrofulous enlargement [48]. Roots are used for cleaning gums, teeth and ulcers, and other dental problems [49].

\section{Ayurvedic view}

The "pongam tree" is known as one of the richest and brightest trees in India. The word "pongamia" has derived from the Tamil word "pinnata" that refers to the "leguminosae" family. In Hindi and Bengali, it is known as Karanj or Paper or Kanji [50]. It is classically categorized in Charaka Samhita as a "Kandughna" that means a group of herbs that relieve itching, Katuka Skandha is a pungent tasting group of herbs. Charaka has mentioned it as a major source of oil [51,52]. Rasa Panchak of Karanj as per Ayurveda is shown in Table 3.

\section{Ayurvedic Uses of Karanj (P. pinnata) [53-55]}

Yonidoshahrut (योनिदोहरहुत)- Detoxifies vaginal diseases, useful in uterine disorders

Kushtaghna (कुष्टघ्द)- Useful in skin diseases

Udavartahara (उदावर्तारा) - relieves bloating

Gulmahara (गुलमोहर)- relieves abdominal tumor, bloating

Arshahara (अर्शाहारा)- useful in piles/hemorrhoids

Krumihara (कृमिहारा)- relieves worm infestation
Table 3: Rasa panchak (properties and action) of Karanj (P. pinnata)

\begin{tabular}{ll}
\hline Sanskrit/English & Sanskrit/English \\
\hline Rasa/Taste & Katu,tikta,kasaya/ \\
& Punjent,Astringent, Bitter \\
Guna/Physical properties & Tiksna/piercing \\
Virya/Potency & Usna/Hot \\
Vipaka/Metabolic properties & Katu/Punjent \\
\hline
\end{tabular}

P. pinnata: Pongamia pinnata

\section{P. pinnata leaves}

Kaphavatahara (कफवताहार)- balances kapha and vata Arshahara (अर्शाहारा)- Useful in piles/hemorrhoids Krumihara (कृमिहारा) - relieves worm infestation Shothahara (शोथाहारा) - relieves inflammation Bhedena (भेडेना) - induces diarrhea, relieves constipation Pittala (पिटला) - increases Pitta

\section{P. pinnata Fruits are}

Kaphavataghna (कफवत्घना) - balances Kapha and Vata Mehahaha (मेहाहा) - Useful in urinary tract disorders and diabetes Arshahara (अरशाहारा) - Useful in piles/hemorrhoids Krumihara (कृमिहारा) - relieves worm infestation

Pongamia oil is a major source of bio-diesel and is used in Ayurveda for external application to shrink the pile mass, to heal wounds and abscesses quickly. It is useful in acne vulgaris, pimples, and secretions [56].

\section{MODERN VIEW}

The consumption of herbal medicines has increased nowadays world widely. Reported studies have revealed an increased growth in the sale of herbal products from the year 2000 to 2008 ranges from $3 \%$ to $12 \%$ per year [57]. Due to the increased demand of herbal products, the risk with herbal medicines also rises. The quality of the end product compromises because of the contamination of raw material with toxic metals, microbes, other residues, and adulteration (addition of fake or inferior plant material, orthodox drugs, foreign material) which results in poor quality of medicinal products [58]. Internal issues such as non-uniformity (rises due to environmental factor and geographical distribution, use of pesticides, fertilizers) and complexity in the 
ingredients of herbal medicines are also raised which affects the quality of herbal medicines [59]. Lack of standardization technique for herbal products is also responsible for the poor quality of drugs because of the failure to detect the original drug which exploits its usage in the conventional system of medicines [60]. The development of new dosage forms without affecting the principal component is the presentday need. Many formulations such as oil, creams, and seed packet are produced from the plant $P$. pinnata. Seed oil has its own medicinal value, due to which it is used for the treatment of rheumatism in humans. Modern science utilized its effect for enhancing the pigmentation of skin in humans affected by leukoderma or scabies [7]. The oil is also used as a lubricant, water-paint binder, pesticide, and in soap-making and tanning industries [7].

\section{PHARMACOLOGICAL AND THERAPEUTIC USES}

Several scientific research/studies showed that this plant consists of various pharmacological activities such as antioxidant, antimicrobial, anti-parasite, anti-inflammatory, anticonvulsant, anti-diabetic, antihyperammonemia, cytotoxicity, anthelminthic, and many others. They are mentioned below:

1. Anti-oxidant properties: The ethanolic extract of the leaves mainly possesses anti-oxidant properties. The experiment was conducted in $\mathrm{NH}_{4} \mathrm{Cl}$-induced hyperammonemia rats and results showed that oral administration $(300 \mathrm{mg} / \mathrm{kg} \mathrm{wt})$ significantly reduced the level of TBARS, HP, and CD and increased the level of superoxide dismutase, catalase, glutathione (GSH) peroxidase, and GSH in the liver and kidney [61]. The flavonoids and polyphenol present in the extract have anti-oxidant properties. One more research states that methanolic extract of the seed increases the level of ferric reducing/ antioxidant power [62]

2. Anti-microbial: The various extracts of the plant consist of the antibacterial activity against a different spectrum of gram-negative and gram-positive bacteria such as Proteus vulgaris, Staphylococcus epidermidis, Staphylococcus aureus, Enterobacter aerogenes, Bacillus subtilis, Salmonella typhimurium, Escherichia coli, Propionibacterium acne, Yersinia enterocolitica, Listeria monocytogenes, Shigella flexneri, and Vibrio cholerae [63]. Chalcone, triterpenes, and aromatic carboxylic acid are the major compounds that possess antimicrobial activity [64]. A test was conducted to evaluate the antifungal property of the plant and it was found that seed oil showed maximum activity against Aspergillus niger followed by Aspergillus terreus and Candida albicans [65]. Cycloart-23-ene-3ß,25-diol is a triterpene compound of this plant which is tested for its antifungal activity. The result showed strong activity against $C$. albicans and no any action against Penicillium notatum [66]. The crude aqueous extract of the seed hindered the growth of herpes simplex virus type-1 (HSV-1) and HSV-2 [67] and showed no any activity against rotavirus [68]. An experiment has shown that oral administration of ethanolic extract of leaves hinders the growth of white spot syndrome virus and increased the survival rate in shrimp up to $40-80 \%$, respectively [69-73]

3. Antiprotozoal: Reported studies revealed that the bark and leaf extract with low $\mathrm{IC}_{50}$ values dry extract showed anti-malarial, antiplasmodial activity against Plasmodium falciparum [74]. Lupeol is the main constituent that blocked the invasion of $P$. falciparum merozoites $[75,76]$ and also inhibited the growth of Trypanosoma cruzi and Leishmania [77]

4. Anti-inflammatory: An experiment was conducted in the rats to evaluate the anti-inflammatory activity of methanolic extract of the seeds which were administrated orally in the dose of $12-50 \mathrm{mg} / \mathrm{kg}$ for the 5 days. The results showed protective effects against a gastric ulcer in the rats $[78,79]$

5. Another study was conducted to evaluate the anti-inflammatory activity against Freund's complete adjuvant-induced arthritis in rats. It was found that the model injected with this polyherbal formulation containing roots of Cissampelos pareira Linn, leaves of M. pinnata (L.) Pierre, and leaves of Vitex negundo Linn. possesses anti-inflammatory properties [80]. This formulation reduces the hind paw swelling and body weight with other improvements in the model
6. Anticonvulsant activity: The experiment was conducted for the treatment of maximal electroshock-induced seizure in Wistar albino mice with the ethanolic extract of the leaves. It was found anticonvulsant property by lowering the duration of extension phase when compared with a control group. Hence, the ethanolic extract of the leaves of this plant have anticonvulsant activities [81,82]

7. Anti-hyperammonemic activity: The level of blood ammonia, circulatory urea, uric acid, non-protein nitrogen, and creatinine decreased significantly in the rats treated with the extract and ammonium chloride. No significant change in the body of the model was found when compared with the control [69]

8. Cytotoxicity: $100 \mathrm{mg} / \mathrm{ml}$ methanolic extract was screened to know the cytotoxicity against the pancreatic adenocarcinoma cell line Panc-1 (human pancreatic cancer) for cytotoxicity. It was used as a label-free biosensor assay. The extract of this plant exhibited antiproliferation activity [83]. Carcache-Blanco et al. state that all the flavonoid compounds were possessing cytotoxicity against cancer cells [84]

9. Anthelminthic activity: The methanolic extract and ethyl acetate extract of the seeds possesses anthelmintic property. It was reported that it needed less time to cause the paralysis and death of adult earthworms, Pheretima posthuma than the extracts of other parts of the plant such as leaves, wood, bark, and fruits [85]

10. Immune modulatory: Reported studies revealed that the aqueous extract of the leaves possesses immunomodulating activity [86]

11. Cardioprotective activity: A study was conducted for the investigation of the cardioprotective activity of P. pinnata in diabetic rats. Diabetes in rats was induces with streptozotocin-nictinamide. As a result, it was found that the stem bark petroleum ether extract was effective on cardiomyopathy in rats [87]

12. Antinociceptive and antipyretic activity: Reported studies state that leaves have antinociceptive and antipyretic behaviors. An experiment was conducted to test the antinociceptive efficacy by injection of $70 \%$ ethanolic extract in the pain models in rats and mice. The finding showed that the leaves have antinociceptive and antipyretic activity [88]

13. Anti-diabetic activity: The flower extract of the P. pinnata administrated orally in diabetic rats significantly decreased blood glucose levels to a degree close to that of the drug glibenclamide. The finding displayed an anti-hyperglycemic effect and also raised the level of plasma insulin significantly [89]

14. Neuroprotective activity: A study showed the neuroprotective impact of stem bark ethanol extract on monosodium glutamate-induced neurotoxicity in albino rats [90]

15. Anti-lice activity: According to recent studies, this medicinal plant is the novel anti-lice agent. An experiment was conducted in which different extracts of P. pinnata leaves in the sample checked against head louse Pediculus humanus capitis. The outcome indicated the anti-lice activity [91,92]

16. Anti-ulcer: Reported studies showed that the methanolic extract of roots of P. pinnata tends to decrease acetic acid-induced ulcers. Ulcer protective effect of methanolic extract of P. Pinnata roots was due to augmentation of mucosal defensive factors such as mucin secretion, the life span of mucosal cells, mucosal cell glycoproteins, and cell proliferation [7]. Reported studies on P. pinnata are listed in Table 4.

\section{SEED OIL AS BIOFUEL}

P. pinnata plant is considered as a source of biodiesel. Oil is extracted from the seeds of the P. pinnata. Seed oil is a thick, yellowish, or reddishbrown having calorific value of $40.756 \mathrm{MJ} / \mathrm{kg}$. The oil is extracted through expeller and solvent extraction. The seeds of karanja contain at least $27-40 \%$ of oil. There are many factors affecting the quality of the oil (biodiesel) such as viscosity, flash point, calorific value, specific gravity, and acid value/free fatty acid content [93]. The free fatty acid content is very high in seed oil of karanja. Biodiesel produced through 2-step transesterification process. The Karanja oil also undergoes in 2 step processes in which acid-esterification done before alkali transesterification [94]. In some supercritical conditions, both the steps can be carried out simultaneously because of the shortage of time [95]. 
Table 4: Reported experimental and clinical studies on $P$. pinnata

\begin{tabular}{|c|c|c|c|c|}
\hline S. No. & Extract & Method (in vivo/in vitro model) & Pharmacological activity & Reference \\
\hline 1. & $\begin{array}{l}\text { Ethanolic extract of leaves, Flavonoids, } \\
\text { and Methanolic extract of seed }\end{array}$ & Hyperammonemic rats & Anti-oxidant properties & 69,70 \\
\hline 2. & $\begin{array}{l}\text { Chalcone, triterpenes and aromatic } \\
\text { carboxylic acid, Crude aqueous } \\
\text { extract, and Ethanolic extract of leaves }\end{array}$ & $\begin{array}{l}\text { P. vulgaris, } S . \text { epidermidis, } S . \text { aureus, } E \text {. } \\
\text { aerogenes, B. subtilis, } S \text {. typhimurium, } \\
\text { E. coli, } P \text {. acne, } Y \text {. enterocolitica, } L . \\
\text { monocytogenes, S. flexneri, and } V . \text { cholerae, } \\
\text { A. terreus and } C \text {. albicans, Shrimp }\end{array}$ & $\begin{array}{l}\text { Anti-bacterial, Anti-fungal, } \\
\text { anti-viral }\end{array}$ & $71-81$ \\
\hline 4. & Methanolic extract & Rats & Anti-inflammatory & $86-88$ \\
\hline 5. & Ethanolic extract & Albino mice & Anticonvulsant activity & 89,90 \\
\hline 6. & Ethanolic extract & Rats & Anti-hyperammonemic activity & 91 \\
\hline 7. & Methanolic extract & Human pancreas & Cytotoxicity & 92,93 \\
\hline 8. & Methanolic extract and ethyl acetate & Rats & Anthelminthic & 94 \\
\hline 9. & Aqueous extract & Rats & Immune modulatory & 94 \\
\hline 10. & Petroleum ether extract & Diabetic rats & Cardioprotective & 96 \\
\hline 11. & Leaves extract & Rat and mice & Antinociceptive and Antipyretic & 97 \\
\hline 13. & Stem bark ethanolic extract & Albino rats & Neuroprotective & 99 \\
\hline 14. & Leaves extract & Rats & Anti-lice & 100,101 \\
\hline 15. & Methanolic extract & Rats & Anti-ulcer & 102 \\
\hline
\end{tabular}

P. pinnata: Pongamia pinnata, P. vulgaris: Proteus vulgaris, S. epidermidis: Staphylococcus epidermidis, S. aureus: Staphylococcus aureus, E. aerogenes: Enterobacter aerogenes, B. subtilis: Bacillus subtilis, S. typhimurium: Salmonella typhimurium, E. coli: Escherichia coli, P. acne: Propionibacterium acne, Y. enterocolitica: Yersinia enterocolitica, L. monocytogenes: Listeria monocytogenes, S. flexneri: Shigella flexneri, V. cholerae: Vibrio cholera, A. terreus: Aspergillus terreus, C. albicans: Candida albicans

Microwave and Cao as a heterogeneous catalyst are used to enhance the transesterification process [104]. The transesterification process addresses some issues like high viscosity, same as other vegetable oils. Therefore, the karanja oil is not suitable for direct use in a diesel engine. After addressing these issues by this process, the quality of karanja oil methyl ester (biodiesel) is produced that is also cost-effective. There is a various method for the production of biodiesel from the karanja oil such as pyrolysis, micro-emulsion, and bleeding [96]. In recent years, Karanja oil is considered as a good commercial option over other mineral fuels. Mofijur et al. showed in his research that the use of various anti-oxidants in the karanja oil improves the oxidation stability, cost-analysis of biodiesel [97].

CONCLUSION

Nature has been a good source of medicinal plant since immemorial time. At present, many modern drugs have been isolated from the plant source. Karanja has been recognized as a medicinal plant in a traditional system for the treatment of various diseases of human beings. Many scientific studies have proved the pharmacological activities of the $P$. pinnata such as anti-ulcer, anti-diarrheal, antiplasmodial, antiinflammatory, anti-viral, anti-bacterial, anti-lice, and many more. Apart from the multiple biological effects, seed oil obtained from this plant is proved to be biodiesel as per recent studies. Conclusively this plant herbal plant is proved to be a multipurpose tree with good economic value.

\section{AUTHORS' CONTRIBUTIONS}

We declare that this work was done by the authors named in this article and all liabilities pertaining to claims relating to the content of this article will be borne by the authors.

Dr. Gitika Chaudhary drafted the article and contributed in writing Ayurvedic view of the article Dr. Hemlata Kaurav contributed in drafting and writing pharmacological portion of plant. Shifali Thakur contributed in data collection and writing the paper

\section{CONFLICTS OF INTEREST}

No potential conflicts of interest were reported by the authors.

\section{AUTHORS' FUNDING}

No any funding for this article writing.

\section{REFERENCES}

1. Baker JT, Borris RP, Carté B, Cordell GA, Soejarto DD, Cragg GM, et al. Natural product drug discovery and development: New perspectives on international collaboration. J Nat Prod 1995;58:1325-57.

2. Bala M, Nag TN, Kumar S, Vyas M, Kumar A, Bhogal NS. Proximate composition and fatty acid profile of Pongamia pinnata, a potential biodiesel crop. J Am Oil Chem Soc 2011;88:559-62.

3. Sangwan S, Rao DV, Sharma RA. A review on Pongamia pinnata (L.) Pierre: A great versatile leguminous plant. Nat Sci 2010;8:130-9.

4. Divakara BN, Alur AS, Tripati S. Genetic variability and relationship of pod and seed traits in Pongamia pinnata (L.) Pierre., a potential agroforestry tree. Int J Plant Prod 2012;4:129-42.

5. Ramadevi D, Rao BG, Reddy SJ. Phytochemical and pharmacological studies on Pongamia pinnata. Paripex Indian J Res 2018;7:489-92.

6. Tanaka T, Inuma M, Yuki K, Fujii Y, Mizuno M. Flavonoids in root bark of Pongamia pinnata. Phytochemistry 1992;31:993-8.

7. Chopade VV, Tankar AN, Pande VV, Tekade AR, Gowekar NM, Bhandari SR, et al. Pongamia pinnata: Phytochemical constituents, traditional uses and pharmacological properties: A review. Int J Green Pharm 2008;2:72-5.

8. Meera B, Kumar S, Kalidhar SB. A review of the chemistry and biological activity of Pongamia pinnata. J Med Aromat Plant Sci 2003;25:441-5.

9. Meher LC, Dharmagadda VS, Naik SN. Optimization of alkalicatalyzed transesterification of Pongamia pinnata oil for production of biodiesel. Bioresour Technol 2006;97:1392-7.

10. Kumar D, Singh B, Sharma YC. Bioenergy and phytoremediation potential of Millettia pinnata. In: Phytoremediation Potential of Bioenergy Plants. Singapore: Springer; 2017. p. 169-88

11. Arpiwi NL, Yan G, Barbour EL, Plummer JA. Genetic diversity, seed traits and salinity tolerance of Millettia pinnata (L.) Panigrahi, a biodiesel tree. Genet Resour Crop Evol 2013;60:677-92.

12. Yadav RD, Jain SK, Alok S, Prajapati SK, Verma A. Pongamia pinnata: An overview. Int J Pharm Sci Res 2011;2:494.

13. The Ayurvedic Pharmacopoeia of India, Part-I; 1996. p. 80-8

14. Allen ON, Allen EK. The Leguminosae. Wisconsin: The University of Wisconsin Press; 1981. p. 812.

15. Gilman EF. Associate Professor, Environmental Horticulture Department, Dennis G Watson, Associate Professor, Agricultural Engineering Department, Cooperative Extension Service, Institute of 
Food and Agricultural Sciences, University of Florida, Gainesville FL; 2004. p. 32611.

16. Lucas DS. Dravyaguna Vijnana. $1^{\text {st }}$ ed., Vol. 2. Varanasi: Chaukhamba Bharati; 2008.

17. Hartwell JL. Plants used against cancer. A survey. Lloydia 1971;34:30-4.

18. Wagh P, Rai M, Deshmukh SK, Durate MC. Bio-activity of oils of Trigonella foenum-graecum and Pongamia pinnata. Afr J Biotechnol 2007;6:1592-6.

19. Krishnamurthi A. The Wealth of India. Vol. 8. New Delhi, India: Publication and Information Directorate CSIR; 1969.

20. Aiman R. Recent research on indigenous anti diabetic medicinal plantsan overall assessment. Indian J Physiol Pharmacol 1970;14:6576.

21. Koysomboon S, Altena IV, Kato S, Chantrapromma K Antimycobacterial flavonoids from Derris indica. Phytochemistry 2006;67:103440

22. Chopra RN, Chopra IC. Indigenous Drugs of India. Calcutta: Academic Publishers; 1934. p. 325.

23. Limaye DB. Karanjin Part I: A crystalline constituent of the oil from P. glabra. Vol. 118. In: Proceedings of the $12^{\text {th }}$ Indian Academy of Science Congress; 1925.

24. Rao RR, Tiwari AK, Reddy PP, Babu KS, Ali AZ, Madhusudana K, et al. New furanoflavanoids, intestinal $\alpha$-glucosidase inhibitory and free-radical (DPPH) scavenging, activity from antihyperglycemic root extract of Derris indica (Lam.). Bioorg Med Chem 2009;17:5170-5.

25. Talapatra SK, Mallik AK, Talapatra B. Pongaglabol, a new hydroxyfuranoflavone, and aurantiamide acetate, a dipeptide from the flowers of Pongamia glabra. Phytochemistry 1980;19:1199-202.

26. Pathak VP, Saini TR, Khanna RN. A new furanoflavone from seeds of Pongamia glabra. Planta Med 1983;49:61.

27. Saha MM, Mallik UK, Mallik AK. A chromenoflavanone and two caffeic esters from Pongamia glabra. Phytochemistry 1991;30:3834-6.

28. Pavanaram SK, Row LR. New flavones from Pongamia pinnata (L.) Merr.: Identification of compound D. Nature 1955;176:1177.

29. Khanna RN, Seshadri TR. Pongaglabrone, a new component of the seeds of Pongamia glabra: Its constitution and synthesis. Tetrahedron 1963;19:219-25.

30. Talapatra SK, Mallik AK, Talapatra B. Isopongaglabol and 6-methoxyisopongaglabol, two new hydroxyfuranoflavones from Pongamia glabra. Phytochemistry 1982;21:761-6.

31. Kanungo PD, Ganguly A, Guha A, Bhattacharyya A, Adityachaudhury N. Glabone, a new furanoflavone from Pongamia glabra. Phytochemistry 1987;26:3373-4.

32. Yin H, Zhang S, Wu J, Nan H, Long L, Yang J, et al. Pongaflavanol: A prenylated flavonoid from Pongamia pinnata with a modified ring A. Molecules 2006;11:786-91

33. Mukerjee SK, Sarkar SC, Seshadri TR. The structure and synthesis of pongachromene, a new component of Pongamia glabra. Tetrahedron 1969;25:1063-9.

34. Carcache-Blanco EJ, Kang YH, Park EJ, Su BN, Kardono LB, Riswan S, et al. Constituents of the stem bark of Pongamia p innata with the potential to induce quinone reductase. J Natl Prod 2003;66:1197-202.

35. Ahmad G, Yadav PP, Maurya R. Furanoflavonoid glycosides from Pongamia pinnata fruits. Phytochemistry 2004:65:921-4

36. Marzouk MS, Ibrahim MT, El-Gindi OR, Bakr MS. Isoflavonoid glycosides and rotenoids from Pongamia pinnata leaves. Z Naturforsch C J Biosci 2008;63:1-7.

37. Li L, Li X, Shi C, Deng Z, Fu H, Proksch P, et al. Pongamone A-E, five flavonoids from the stems of a mangrove plant, Pongamia pinnata. Phytochemistry 2006;67:1347-52.

38. Boligon AA, Agertt V, Janovik V, Cruz RC, Campos M, Guillaume D, et al. Antimycobacterial activity of the fractions and compounds from Scutia buxifolia. Rev Bras Farmacogn 2012;22:45-52.

39. Kitagawa I, Zhang RS, Hori K, Tsuchiya K, Shibuya H. Indonesian medicinal plants. II. Chemical structures of pongapinones A and $\mathrm{B}$, two new phenylpropanoids from the bark of Pongamia pinnata (Papilionaceae). Chem Pharm Bull 1992;40:2041-3.

40. Minakawa T, Toume K, Ahmed F, Sadhu SK, Ohtsuki T, Arai MA, et al. Constituents of Pongamia pinnata isolated in a screening for activity to overcome tumor necrosis factor-related apoptosis-inducing ligandresistance. Chem Pharm Bull 2010;58:1549-51.

41. Yin $\mathrm{H}$, Zhang $\mathrm{S}, \mathrm{Wu}$ J, Nan $\mathrm{H}$. Dihydropyranoflavones from Pongamia pinnata. J Braz Chem Soc 2006;17:1432-5.

42. Gupta RK, Krishnamurti M. Chromenoflavones from Millettia ovalifolia. Phytochemistry 1976. p. 15

43. Rangaswami S, Rao JV, Seshadri TR. Kanugin, a crystalline component of the roots of Pongamia glabra. In: Proceedings of the Indian Academy of Sciences-Section A. Vol. 16. India: Springer; 1942. p. 319.
44. Mahalik G. Comparative analysis of phytochemical and antimicrobial activity of Butea monosperma (Lam.) Taub. and Pongamia pinnata (L.) Pierre: A review. Indian J Nat Sci 2020;10:19368-73.

45. Kumar D, Kumar A, Prakash O. Pharmacognostic evaluation of stem bark of Pongamia pinnata (L.) Pierre. Asian Pac J Trop Biomed 2012;2:S543-6.

46. Shameel S, Usmanghani K, Ali MS, Ahmad VU. Chemical constituents from the seeds of Pongamia pinnata (L.) Pierre. Pak J Pharm Sci 1996;9:11-20.

47. Ghani A. Medicinal Plants of Bangladesh. Dhaka, Bangladesh: Asiatic Society of Bangladesh; 1998. p. 270

48. Satyavati GV, Gupta AK, Neeraj T. Medicinal Plants of India. Vol. 2. New Delhi: ICMR; 1987. p. 490.

49. Kirtikar KR, Basu BD. Indian Medicinal Plants. $2^{\text {nd }}$ ed., Vol. 1. India: Dehradun Publisher Ltd.; 1994. p. 830-2.

50. Pole S, Sebastian J. Ayurvedic Medicine. London: Churchill Livingstone; 2006

51. Mudgal D. Dravyagun Vigyan. Rajasthan: Ayurveda Sanskrit Hindi Pustak Bhandar; 2019.

52. Pandey G. Dravyaguna Vijnana. Varanasi: Chowkhamba Krishnadas Academy; 2004

53. Sharma PV. Dravyagun Vigyan. Varanasi: Chaukambha Bharti Academy; 2019.

54. Mukherjee PK. Quality Control of Herbal Drugs: An Approach to Evaluation of Botanicals. Netherlands: Business Horizons; 2002.

55. Judd WS, Campbell CS, Kellogg EA, Stevens PF, Donoghue MJ. Plant systematics: A phylogenetic approach. United States: Sinauer Axxoc; 2002. p. 287-92.

56. Ingredient Guide. Function and Active Cosmetic Ingredients for Skin and Hair. England: Ashford, Kent; 2006. p. 9.

57. Chopra RN. Indigenous Drugs of India. Calcutta: Academic Publishers; 1933. p. 388

58. Organización Mundial de la Salud, World Health Organization, Swiatowa Organizacja Zdrowia. WHO Guidelines on Good Agricultural and Collection Practices [GACP] for Medicinal Plants. Geneva: World Health Organization; 2003

59. Ernst E. Herbal Medicines-they are Popular, but are they Also Safe? 2006.

60. Yee SK, Chu SS, Xu YM, Choo PL. Regulatory control of Chinese proprietary medicines in Singapore. Health Policy 2005;71:133-49.

61. Essa MM, Subramanian P. Protective role of Pongamia pinnata leaf extract on tissue antioxidant status and lipid peroxidation in ammonium chloride-induced hyperammonemic rats. Toxicol Mech Methods 2006; $16: 477-83$

62. Patil P, Prakash T, Shivakumar H, Pal S. Anti-ulcer and anti-secretory properties of the Butea monosperma (Lam) bark extract with relation to anti-oxidant studies. Iran J Pharmacol Ther 2009;8:1-6.

63. Arote SR, Dahikar SB, Yeole PG. Phytochemical screening and antibacterial properties of leaves of Pongamia pinnata Linn. (Fabaceae) from India. Afr J Biotechnol 2009;8:6393-6.

64. Bajpai VK, Rahman A, Shukla S, Mehta A, Shukla S, Arafat SY, et al. Antibacterial activity of leaf extracts of Pongamia pinnata from India. Pharm Biol 2009; 47:1162-7.

65. Kesari V, Das A, Rangan L. Physico-chemical characterization and antimicrobial activity from seed oil of Pongamia pinnata, a potential biofuel crop. Biomass Bioenergy 2010;34:108-15.

66. Badole SL, Zanwar AA, Ghule AE, Ghosh P, Bodhankar SL. Analgesic and anti-inflammatory activity of alcoholic extract of stem bark of Pongamia pinnata (L.) Pierre. Biomed Aging Pathol 2012;2:19-23.

67. Elanchezhiyan M, Rajarajan S, Rajendran P, Subramanian S, Thyagarajan SP. Antiviral properties of the seed extract of an Indian medicinal plant, Pongamia pinnata, Linn., against herpes simplex viruses: In vitro studies on Vero cells. J Med Microbiol 1993;38:262-4.

68. Brijesh S, Daswani PG, Tetali P, Rojatkar SR, Antia NH, Birdi TJ. Studies on Pongamia pinnata (L.) Pierre leaves: Understanding the mechanism (s) of action in infectious diarrhea. J Zhejiang Univ Sci B 2006;7:665-74.

69. Rameshthangam PA, Ramasamy P. Antiviral activity of bis (2-methylheptyl) phthalate isolated from Pongamia pinnata leaves against white spot syndrome virus of Penaeus monodon Fabricius. Virus Res 2007;126:38-44

70. Amoros M, Simõs CM, Girre L, Sauvager F, Cormier M. Synergistic effect of flavones and flavonols against herpes simplex virus Type 1 in cell culture. Comparison with the antiviral activity of propolis. J Nat Prod 1992;55:1732-40

71. Ono K, Nakane H, Fukushima M, Chermann JC, Barré-Sinoussi F. 
Differential inhibitory effects of various flavonoids on the activities of reverse transcriptase and cellular DNA and RNA polymerases. Eur J Biochem 1990;190:469-76.

72. Middleton E Jr. The impacts of plant flavonoids on mammalian biology: Implications for immunity, inflammation and cancer. In: The flavonoids: Advances in Research Since 1986; 1993. p. 337-70.

73. Hernández-Pérez M, López-García RE, Rabanal RM, Darias V, Arias A. Antimicrobial activity of Visnea mocanera leaf extracts. J Ethnopharmacol 1994;41:115-9.

74. Simonsen HT, Nordskjold JB, Smitt UW, Nyman U, Palpu P, Joshi P, et al. In vitro screening of Indian medicinal plants for antiplasmodial activity. J Ethnopharmacol 2001;74:195-204.

75. Suksamrarn A, Tanachatchairatana T, Kanokmedhakul S. Antiplasmodial triterpenes from twigs of Gardenia saxatilis. J Ethnopharmacol 2003;88:275-7.

76. Ziegler HL, Franzyk H, Sairafianpour M, Tabatabai M, Tehrani MD, Bagherzadeh $\mathrm{K}$, et al. Erythrocyte membrane modifying agents and the inhibition of Plasmodium falciparum growth: Structureactivity relationships for betulinic acid analogues. Bioorg Med Chem 2004; 12:119-27.

77. Fournet A, Angelo A, Muñoz V, Roblot F, Hocquemiller R, Cavé A. Biological and chemical studies of Pera benensis, a Bolivian plant used in folk medicine as a treatment of cutaneous leishmaniasis. J Ethnopharmacol 1992;37:159-64.

78. Prabha T, Babu MD, Priyambada S, Agrawal VK, Goel RK. Evaluation of Pongamia pinnata root extract on gastric ulcers and mucosal offensive and defensive factors in rats. Indian J Exp Biol 2003;41:304-10.

79. Prabha T, Dorababu M, Goel S, Agarwal PK, Singh A, Joshi VK, et al. Effect of methanolic extract of Pongamia pinnata Linn seed on gastroduodenal ulceration and mucosal offensive and defensive factors in rats. Indian J Exp Biol 2009;47:649-59.

80. Eipeson WS, Manjunatha JR, Srinivas P, Kanya TS. Extraction and recovery of karanjin: A value addition to Karanja (Pongamia pinnata) seed oil. Ind Crops Prod 2010;32:118-22.

81. Manigauha A, Patel S, Monga J, Ali H. Evaluation of anticonvulsant activity of Pongamia pinnata Linn in experimental animals. Int J Pharm Technol Res 2009;4:1119-21.

82. Al Muqarrabun LM, Ahmat N, Ruzaina SA, Ismail NH, Sahidin I. Medicinal uses, phytochemistry and pharmacology of Pongamia pinnata (L.) Pierre: A review. J Ethnopharmacol 2013;150:395-420.

83. George LO, Radha HR, Somasekariah BV. In vitro anti-diabetic activity and GC-MS analysis of bioactive compounds present in the methanol extract of Kalanchoe pinnata. Indian J Chem 2018;57B:1213-21.

84. Kinghorn AD, Su BN, Jang DS, Chang LC, Lee D, Gu JQ, et al. Natural inhibitors of carcinogenesis. Planta Med 2004;70:691-705.

85. Nirmal SA, Malwadkar G, Laware RB. Anthelmintic activity of Pongamia glabra. Songklanakarin J Sci Technol 2007;29:755-7.

86. Manikannan M, Durgadevi P, Subramaniyan S, Manickan E. Abundant CD4 Th-2 cytokine stimulation by medicinal plant Pongamia pinnata Linn. on human peripheral blood mononuclear cell (PBMC). Int J Plant Physiol Biochem 2012;4:27-32.

87. Manigauha A, Patel S. Pentylenetetrazole induced convulsion in RATS. Int J Pharm Biosci 2010;1:2.

88. Srinivasan K, Muruganandan S, Lal J, Chandra S, Tandan SK, Raviprakash V, et al. Antinociceptive and antipyretic activities of Pongamia pinnata leaves. Phytother Res 2003;17:259-64.

89. Punitha R, Vasudevan K, Manoharan S. Effect of Pongamia pinnata flowers on blood glucose and oxidative stress in alloxan induced diabetic rats. Indian J Pharmacol 2006;38:62.

90. Swamy HM, Patel NL, Gadad PV, Koti C, Patel HM, Thippeswamy C, et al. Neuroprotective activity of Pongamia pinnata in monosodium glutamate-induced neurotoxicity in rats. Indian J Pharm Sci 2013;75:657-63.

91. Mumcuoglu KY. Prevention and treatment of head lice in children. Paediatr Drugs 1999;1:211-8.

92. Yang YC, Lee HS, Clark JM, Ahn YJ. Insecticidal activity of plant essential oil against Pediculus humanus Capitis (Anoplura: Pediculidae). J Med Entomol 2004;41:699-704.

93. Dwivedi G, Sharma MP. Prospects of biodiesel from Pongamia in India. Renew Sustain Energy Rev 2014;32:114-22.

94. Joshi G, Rawat DS, Lamba BY, Bisht KK, Kumar P, Kumar N, et al. Transesterification of Jatropha and Karanja oils by using waste egg shell derived calcium based mixed metal oxides. Energy Convers Manag 2015;96:258-67.

95. Takase M, Zhao T, Zhang M, Chen Y, Liu H, Yang L, et al. An expatriate review of neem, Jatropha, Rubber and Karanja as multipurpose nonedible biodiesel resources and comparison of their fuel, engine and emission properties. Renew Sustain Energy Rev 2015;43:495-520.

96. Patel RL, Sankhavara CD. Biodiesel production from Karanja oil and its use in diesel engine: A review. Renew Sustain Eng Rev 2017;71:464-74.

97. Mofijur M, Rasul M, Hyder J, Azad AK, Mamat R, Bhuiya MM. Role of biofuel and their binary (diesel-biodiesel) and ternary (ethanolbiodiesel-diesel) blends on internal combustion engines emission reduction. Renew Sustain Energy Rev 2016;53:265-78. 